\section{Student Activism Remains a Potent Force Worldwide}

\section{Philip G. Altbach and Manja Klemencic}

Philip G. Altbach is research professor and director of the Center for International Higher Education at Boston College. Manja Klemencic is postdoctoral fellow, Department of Sociology, Harvard University. E-mail:manja.klemencic@gmail.com. (This article has appeared in Inside Higher Education.)

tudents were a key force in toppling Ukrainian autocrat $\checkmark$ Victor Yanukovych. They were on the Maidan battleground in Kiev from beginning to end. They were also instrumental in the 2004 Orange Revolution in the aftermath of that year's presidential election, which was marred by corruption and outright electoral fraud. Students were active on Tahrir Square in Cairo when Hosni Mubarak was forced from office, and they were active participants in all of the Arab Spring movements.

The beginnings of student-dominated youth movements in "color revolutions" come probably with the Serbian Otpor ("Resistance") movement, which was started in I998 as a response to the repressive university and media laws introduced by the regime at the time led by Slobodan Milocevic. In 2000, Otpor organized a campaign "Gotov je" ("He is finished"), ultimately leading to Milocevic's defeat in elections. Organizations such as Kmara in Georgia, active in the Rose Revolution in 2003, KelKel in Kyrgystan in the 2005 Tulip Revolution, and Pora in Ukraine were all inspired and trained by Otpor. Students occupied the Taiwan legislature protesting a trade agreement with China for several weeks in March 20I4-and spearheaded a protest rally of ı००,०००.

Although the era of student revolutions may have ended a half century ago, students continue to be active in politics, and they are often a key force in political movements directed toward social change around the world. Students may no longer be at the center of political movements, but they are often indispensable participants, frequently helping to shape the messages, ideologies, and tactics of protest movements.

Students have also been engaged in university politics and policy. German students successfully pushed to have free higher education restored, convincing politicians and the public. Similarly, high school and university students in Chile demonstrated for extended periods to improve educational quality, end for-profit education, and eliminate tuition and fees. They finally succeeded when Michelle Bachelet won the presidency in 20I3. In Canada, the "Maple Spring" protests in 2012 emerged from students' opposition to the government's announcement of increased tuition fees and led to the fall of Québec's government.

In some parts of the world, student agitation, often relating to campus issues, cause governments to shut universities for extended periods. This has occurred in Nigeria, and universities in Myanmar were closed for several years after student protests against the military dictatorship. In many of these cases, student demands have combined local campus issues with broader political concerns. They seldom had success in social change, although sometimes university policies or conditions have altered.

Despite continuing activism and impressive but often ignored success, student activism has not received the scholarly attention that it once did. This may be because movements that may originate on the campus often move quickly off the campus and to the streets and involve many other segments of society. Unlike the ig6os, when students were often both the originators and main participants in protest movements, more recent movements have involved a wider section of the population. Students often lost control over the protests, and in fact in some cases student leaders left the campus to run for public office or participate in a broader leadership coalition. Nonetheless, students have remained a key spearhead for oppositional movements and protests.

\section{Students were a key force in toppling Ukrainian autocrat Victor Yanukovych. They were on the Maidan battleground in Kiev from beginning to end.}

\section{The “Iron LaW" of Student Activism}

There is an iron law of student political activism. Students can often bring public attention to political issues and, when there is an undercurrent of discontent, may help to create political movements that may destabilize or even defeat regimes. As a social group, students tend to have the leisure of time to exchange and develop ideas and organize within the tightly knit university environment; and the public tends to be sympathetic to students' concerns.

But students cannot control national politics once a regime is removed. They may infiltrate political parties; but, in the wider political arena, the typically adversary and non-compromising voices of student activists do not get far. Societal politics is generally about political power vested in economic and military resources, in ability to build alliances and forge compromises. While energetic and driven, 
if students enter the political arena, they may become only a marginal voice-since they seldom possess the substantial and procedural knowledge, experience, and networks required for the larger political stage.

Indeed, in most cases, politics after the end of the social movement moves in directions quite different than advocated by the students. Thus, students may be a precipitating force for social and political change, but never control the outcomes.

Events in both Egypt and Ukraine support the "iron law." Students in general did not favor the ascendance of the Muslim Brotherhood to power following the Arab Spring, nor were students in general happy with some of the ultranationalist forces that became influential in the recent Ukrainian events.

\section{Success on the Educational Front}

Students have sometimes had better success with educational issues. Although massive student demonstrationsand the opposition of British academics - failed to keep high tuition fees from being imposed in England and Wales, students were successful in Germany in rolling back tuition charges so that all of the German states are now committed to free higher education. Protracted demonstrations by high school and university students in Chile resulted in major education reforms and the roll-back of previously high student tuition fees.

The contemporary student protests on the educational front tend to be against cuts in public finding of higher education and increases in tuition fees, both of which are associated with neoliberal reforms in higher education. Austerity measures, following the global financial crisis, have accelerated the implementation of such reforms in countries where they previously did not exist. Although the differences between countries continue to be pronounced, a sense exists nevertheless that the national higher education systems are becoming more alike in the sense of being more market-oriented, even in countries with a strong social-welfare tradition.

The fight against tuition fees remains the single most powerful mobilizing force for student activism worldwide. Other social-welfare concerns-such as availability of student housing, subsidized food and transportation-occasionally lead to more localized types of protests initiated by the local student unions and typically also fairly quickly resolved. Quality assurance is almost never an issue salient enough to mobilize students to political action. These questions are handled by the elected student representatives, who consult the universities voicing student expectations and their satisfaction.

\section{1st Century Student Activism}

Many argued that student activism would disappear in the era of higher education massification. Diverse student populations, part-time study for many, the non-elite social backgrounds of most students, the increasingly high cost of higher education in many countries, and other factors all argued against active political and social engagement. This clearly has not been the case. Students remain a potent political and social engagement. This clearly has not been the case. Students remain a potent political and social force, and only the modes of their involvement have been changing. Students are less likely to vote and less likely to join political parties..

But they more likely take part in online petitions, join boycotts, express views in online forums, involve themselves in advocacy social networks, and participate in demonstrations and protest movements. The nature of student activism still very much depends on which part of the globe is being considered. As the World Values Surveys depict, in Western societies where entire value systems have shifted to postmodernism, students are becoming more individualistic and perhaps more interested in subjective well-being, self-expression, and quality of life.

\section{There is an iron law of student political activism. Students can often bring pub- lic attention to political issues and, when there is an undercurrent of discontent, may help to create political movements that may destabilize or even defeat re- gimes}

There are other societies where democratization, including minority rights, freeing political processes and institutions from corruption, and so forth, remain salient and compelling issues. Even in postmodern postindustrial societies, some students remain politically engaged-as evidenced by student involvement in the "occupy" movements and student participation demonstrations against tuition increases in England. The potential grievances that may mobilize students into student movements for social change are obviously very different, depending on which part of the world being considered. 